\title{
Species identification of ancient Lithuanian fish remains using collagen fingerprinting
}

DOI:

10.1016/j.jas.2018.07.006

\section{Document Version}

Accepted author manuscript

Link to publication record in Manchester Research Explorer

\section{Citation for published version (APA):}

Harvey, V. L., Daugnora, L., \& Buckley, M. (2018). Species identification of ancient Lithuanian fish remains using collagen fingerprinting. Journal of Archaeological Science, 98, 102-111. https://doi.org/10.1016/j.jas.2018.07.006

\section{Published in:}

Journal of Archaeological Science

\section{Citing this paper}

Please note that where the full-text provided on Manchester Research Explorer is the Author Accepted Manuscript or Proof version this may differ from the final Published version. If citing, it is advised that you check and use the publisher's definitive version.

\section{General rights}

Copyright and moral rights for the publications made accessible in the Research Explorer are retained by the authors and/or other copyright owners and it is a condition of accessing publications that users recognise and abide by the legal requirements associated with these rights.

\section{Takedown policy}

If you believe that this document breaches copyright please refer to the University of Manchester's Takedown Procedures [http://man.ac.uk/04Y6Bo] or contact uml.scholarlycommunications@manchester.ac.uk providing relevant details, so we can investigate your claim.

\section{OPEN ACCESS}


Virginia L. Harvey ${ }^{1}$, Linas Daugnora ${ }^{2}$ and Michael Buckley ${ }^{1 *}$

${ }^{1}$ School of Earth and Environmental Sciences, The University of Manchester, Manchester Institute of Biotechnology, Manchester, M1 7DN, United Kingdom

${ }^{2}$ Klaipeda University, Institute of Baltic Region History and Archaeology, Herkaus Manto str. 84, LT-92294 Klaipeda, Lithuania

*Corresponding author: m.buckley@manchester.ac.uk

\begin{abstract}
Morphological identification of ancient bone is often problematic due to heavy fragmentation that generally influences zooarchaeological assemblages. Fish bones are more taphonomically sensitive than those of other vertebrates as they are typically smaller and less biomineralised. Thus, taxonomic identification based on the preservation of morphological features is often extremely limited and can reduce or eliminate the usefulness of an assemblage for inferring taxon information. Currently, one of the most time- and cost-efficient methods of achieving faunal identity from ancient bone is by the collagen fingerprinting technique known as ZooMS (Zooarchaeology by Mass Spectrometry). ZooMS harnesses the potential of preserved collagen, which is the most dominant and timestable protein in bone. In this research, ZooMS is applied to ancient Baltic region fish assemblages that are between 500 and 6000 years old in order to define species identity and construct assemblage compositions. Alongside inferences into environmental and biological shifts from the Neolithic era to present day in the Baltic region, we demonstrate for the first time the ability to distinguish between recently diverged members of the Salmo (salmon) and Scophthalmus (turbot) genera. ZooMS analysis highlights $7 \%$ of the collagencontaining assemblage as having been morphologically identified incorrectly and has facilitated taxonomic refinement of a further $28 \%$ of samples, including some of the morphologically indeterminate bone fragments. This research emphasises the great potential of ZooMS in identifying ichthyoarchaeological bone remains to species-level, and provides a case for the use of collagen fingerprinting in contributing to baseline fisheries and ecological data to inform modern management.
\end{abstract}

Key words: Zooarchaeology, ZooMS, collagen fingerprinting, species identification, fish bone, Baltic Sea, Lithuania , ichthyoarchaeology 


\section{Introduction}

The Baltic Sea is a young, shallow, semi-enclosed sea that was carved from the last glaciation event. Today the sea covers an area of $415,000 \mathrm{~km}^{2}$ (Emeis et al., 2002) and features the coastlines of many countries, including Lithuania. The modern Baltic Sea features a range of salinities extending from low-salinity (near-freshwater) environments on the eastern edge and on the upper surface of the sea, to high salinity environments in the west and at depth that support ecosystems of marine origin (Emeis et al., 2002; Harff et al., 2007; Mohrholz et al., 2015).

\subsection{Brief History of Fishing in Lithuania}

The history of the Baltic Sea from the last glacial event to the Holocene is rich in evidence of past human activities, particularly near the coasts. In the last 14,000 yr BP (years before present), the sea has endured vast alterations in environmental conditions (climate, temperature, salinity), which have been accompanied by shifts in biota (Weckström et al., 2017). The Mesolithic communities in Lithuanian territorial waters favoured the complex ecotopes of river mouths and findings of stationary fishing constructions dating to $8505 \mathrm{yr}$ BP (the oldest known of their kind in the Baltic region) demonstrate early exploitation of freshwater fish in these regions (Girininkas and Žulkus, 2017). The Mesolithic people showed preference towards harvesting salmon (Salmo salar), carp (Carassius carassius), perch (Perca fluviatilis) and catfish (Silurus glanis) (Sloka, 1986; Zagorska, 1992), and are likely to have used hunting tools such as daggers, spears, fish traps, harpoons and hooks (Enghoff, 1994; Meadows et al., 2014), with the latter tradition being notably common throughout Mesolithic Europe (Gramsch et al., 2013). Fishing with mesh nets in the Baltic region began in the late Mesolithic (7000-5300 yr BP) and continued into the Neolithic and beyond, indicated by a prevalence of smaller fish bones being found alongside larger ones in ancient assemblages (Olson and Walther, 2007; Piličiauskas et al., 2015).

The transition to farming brought about the end of the Mesolithic and the beginning of the Neolithic period, approximately 5500 yr BP in Lithuania (Piličiauskas et al., 2012). In these times, although agricultural practices and animal husbandry were slowly being implemented, hunting and fishing were still dominant and stable methods of acquiring sustenance (Rimantienè, 1992a; Daugnora and Girininkas, 1996; Piličiauskas et al., 2012; Girininkas and Daugnora, 2015). The fishermen of Neolithic Lithuania were proficient, typically using nets as their primary catchment method and targeting large predatory fish such as the northern pike (Esox lucius) (Rimantienè, 1992a; Rimantienè, 2005; Stančikaitè et al., 2009). Neolithic archaeological collections, such as that of the Šventoji region of north-west Lithuania and lake settlements of the south-east, are famed for their exceptionally preserved artifacts (Rimantienè, 1992b; Daugnora and Girininkas, 1996; Piličiauskas et al., 2012; Girininkas and Daugnora, 2015). Radiocarbon dates of such artifacts demonstrate the regions were occupied from at least 6000-2800 yr BP, a period following the maximal Littorina Sea transgression at 7500 yr BP (Daugnora and Girininkas, 2004; Rimantienè, 2005; Damušytè, 2011; Piličiauskas et al., 2012) - one of the four recognised stages in the post-glacial progression of the Baltic basin (Andrén et al., 2011). This marine phase, the first connection between the Baltic lake system and the North Sea, established favourable conditions for the exploitation of aquatic resources by early settlers (Jöns, 2011; Girininkas and Daugnora, 2015). The marine bay was then separated from the North Sea by a sandy bar, forcing a semi-open lagoon dated $\sim 200-3500$ yr BP, which favoured a freshwater environment interspersed with further intrusions of brackish water as a consequence of weather extremes and further regression events (Stančikaitè et al., 2009; Andrén et al., 2011; 
Piličiauskas et al., 2012). These environmental shifts can be evidenced through sediment analyses (Andrén et al., 2000), and through the study of ancient fish bone deposits to identify species that are halophilic (marine), such as brill (Scophthalmus rhombus) or halophobic (freshwater), such as pike (E. lucius) (Daugnora and Girininkas, 2004; Stančikaite et al., 2009; Girininkas and Daugnora, 2015). In the early Neolithic period, settlements became more pronounced at the junctions between rivers and seaside lagoons (Lõugas, 1997), and these lagoons were becoming increasingly more saline due to influences from the North Sea (Andrén et al., 2011; Piličiauskas et al., 2012). By the middle and late Neolithic, the diversity of freshwater, diadromous and seawater species being caught was increasing, with greater proportions of marine species typically being targeted as the Neolithic era progressed (Enghoff, 1994; Lõugas, 1997; Enghoff, 1999; Makowiecki, 2003; Daugnora and Girininkas, 2004).

A high dependency on aquatic food resources continued into medieval Lithuania whereby an expansion in fish trade and commercial exchange ensured the retention of fishing practices throughout the middle ages (Zvelebil, 2006; Piličiauskas et al., 2012). Here, catch preference steered again towards more marine-based methods of harvesting, in part due to demand intensification but also as a result of a reduction in freshwater fish stocks (Barrett et al., 2011; Lotze et al., 2014). For example, during the archaeological investigation at the Medieval site of Klaipeda Castle (north-west Lithuanian coast; $14-17^{\text {th }}$ century), a 5-6 m thick cultural layer was unearthed containing over 3000 artifacts, of which 800 were fishhooks and fish bones (Žulkus, 2002). In the late $14^{\text {th }}$ century the main species of interest for the castle's inhabitants included bream (Abramis brama), twait shad (Alosa fallax), pikeperch (Sander lucioperca) and pike (E. lucius). However, into the $15^{\text {th }}$ century the menu incorporated increasingly brackish/marine or diadromous species, including cod (G. morhua), Atlantic salmon (S. salar) and brown sea trout (Salmo trutta trutta), alongside artificially grown carp (Cyprinus carpio) (Žulkus and Daugnora, 2009).

In the Baltic region, the species prevalent in archaeological fish deposits through the ages generally represent the local fish fauna of the region, rather than species that have been brought in through trade (Enghoff, 1999; Žulkus and Daugnora, 2009), although a handful of archaeological analyses have suggested small-scale commercialization and fisheries trade began to take hold from the $11^{\text {th }}-14^{\text {th }}$ centuries (Žulkus and Daugnora, 2009; Orton et al., 2011), with larger and often international enterprises gaining significance well into the $16^{\text {th }}$ century (Holm, 2016). Such harvesting for personal consumption or trade has been changing the Baltic aquatic systems for thousands of years, and anthropogenic pressures have since culminated in a maximal impact during the last 100 years (Rimantienè, 1998; Limburg et al., 2008). Consequently, the Baltic Sea is now recognised as one of the world's most polluted sea areas and is further threatened by overfishing, invasive species introduction, eutrophication and climate change (Weckström et al., 2017; HELCOM, 2017).

\subsection{Faunal Identification using Proteins}

The analysis of historical records (e.g. Gaumiga et al., 2007; MacKenzie et al., 2007) and zooarchaeological material (e.g. Holm, 2016; Yurtseva et al., 2014) can enable ecological reconstructions and provide a greater understanding of aquatic baseline fisheries data prior to the major anthropogenic interferences of the modern era. Such analyses are of key importance in the Baltic Sea, which currently relies on [often underreported] fisheries data from the 1950's onwards to assess biological depletion (Zeller et al., 2011). Where past studies assessing fisheries through zooarchaeological analyses have typically utilised morphological methods of bone identification, other tools are now available for 
zooarchaeologists. For example, preserved proteins such as collagen type I ('collagen (I)') can be harnessed for faunal identification in ancient bone fragments that may otherwise be left unidentified. In this process, termed 'ZooMS' (Zooarchaeology by Mass Spectrometry), collagen (I) is extracted from the bone, enzymatically digested and then the peptide mixture analysed using soft-ionisation mass spectrometry (Buckley et al., 2009). The resulting mass spectrum is called a peptide mass fingerprint (PMF), or more generally a 'collagen fingerprint' as it allows visualisation of the collagen peptides in relation to their mass-tocharge ratios $(\mathrm{m} / \mathrm{z})$. Peptide peaks that can be seen as specific to a particular taxonomic level are referred to as biomarkers and it is a combination of these biomarkers that allows the refinement of taxonomic identification to family level (Buckley et al., 2011), genus level (e.g. Buckley et al., 2017), and occasionally to species level (e.g. Buckley et al., 2016). Liquid chromatography tandem mass spectrometry (LC-MS/MS) can also be employed as a supportive technique to assist in the sequencing of peptide biomarkers using probabilitybased matching. In LC-MS/MS, thousands of peptides from complex proteolytic mixtures can be separated in the first stage of mass spectrometry, and then sequenced in the second stage via collision-induced dissociation (CID). This process generates product ion spectra that detail the $m / z$ of the resulting peptide fragments. When presented with a database of collated protein sequences, probability-based matching allows the inference of specific peptide sequence information that can help interpret homologous biomarkers between taxa (Buckley et al., 2009), or facilitate the building of sequences for phylogenetic analysis (Buckley, 2013).

The collagen (I) molecule is present as a triple helical heterotrimer, with one or more of the three left-handed polypeptide subunits, termed alpha $(\alpha)$ chains, differing in amino acid sequence (Piez, 1965). Collagen (I) in the majority of vertebrates is formed from two identical $\alpha 1$ chains and one chemically dissimilar and quicker evolving $\alpha 2$ chain, each of approximately 1000 amino acids in length (Buckley and Collins, 2011). This formation is termed an ' $(\alpha 1)_{2} \alpha 2_{1}$ ' arrangement. The $\alpha 2$ chain is less restricted in its requirement for the amino acid proline (Pro), promoting a greater variability in sequence between different taxonomic groups (Buckley et al., 2009), whilst still adhering to the obligatory (Gly-XaaYaa) $n$ repeating sequence that typifies the collagen (I) $\alpha$-strands (Kadler et al., 1996). Interestingly however, certain fish species exhibit a more complex heterotrimeric arrangement whereby each of the three $\alpha$ chains differ in sequence to form an ' $\alpha 1_{1} \alpha 2_{1} \alpha 3_{1}$ ' heterotrimer (Piez, 1965). The $\alpha 3$ chain in fish arose from a duplication event of the gene that encodes for the production of the $\alpha 1$ chain (Morvan-Dubois et al., 2003), yet this chain is faster evolving than either of the $\alpha 1$ or $\alpha 2$ chains, facilitating higher levels of sequence variation as a function of evolutionary divergence time (Buckley, 2018).

In this case study we apply ZooMS and LC-MS/MS to ancient Medieval $\left(14^{\text {th }}-17^{\text {th }}\right.$ century) and Neolithic ( $5000-6000 \mathrm{yr}$ BP) fish bone assemblages from Lithuania to examine the potential of these techniques in determining faunal identity. We then aim to explore the capability that this molecular toolset has for assessing past species distributions and inferring fisheries baselines in order to inform modern ecosystem management and recovery programmes for both the Baltic Sea and beyond.

\section{Materials and Methods}

\subsection{Archaeological Sites}

Ancient fish bone samples were collected from a variety of archaeological complexes in Lithuania: Klaipeda City (16-17 ${ }^{\text {th }}$ century), Klaipèda Castle $\left(14-17^{\text {th }}\right.$ century), Šventoji and 
Kretuonas (Neolithic) (Figure 1). In 2013, three trenches were excavated at Klaipeda City's Turgaus Square 12 plot, covering a total area of $399.16 \mathrm{~m}^{2}$ and containing a cultural layer of 1.9-2.7 $\mathrm{m}$ thick. The layer contained an abundant collection of household pottery, structural ceramics, glass artifacts, coins, ornaments and faunal remains, including fish. The Klaipeda Castle site (curtain rampart E), excavated in 2014, was found to comprise a cultural layer 5$6 \mathrm{~m}$ thick, dating to the Medieval period. The site contained numerous bones from fish and other vertebrates, deposited alongside more than 3000 cultural artifacts.

The north-westerly Neolithic complex of Šventoji is a massive archaeological network consisting of around 60 sites, dating 6000-2500 yr BP (Rimantienè, 2005; Heron et al., 2015). Settlements were situated alongside a coastal freshwater lake, transformed from a sea lagoon which transitioned into the Pajūris bog at the end of the Neolithic period (Rimantienè, 1992a). The sites of Šventoji 2, horizon B (2B; excavated in 1967-1969), Šventoji 4, horizon A (4A) and horizon B (4B; discovered in 1986) are dwelling or dumping/refuse zones related to food consumption, situated on the shore of the lagoon (Rimantienè, 1992a; Rimantienè, 1996; Rimantienè, 2005; Heron et al., 2015).

The sites of Kretuonas 1, horizon A (1A; Late Neolithic) and Kretuonas 1, horizon B (1B; Middle Neolithic) are situated near a Neolithic lake region in eastern Lithuania (Daugnora and Girininkas, 1996; Daugnora and Girininkas, 1998). The cultural layers of these settlements contain numerous tools used for hunting and fishing made from wood, stone or, more commonly, the bones of large ungulates (Daugnora and Girininkas, 1995). Though there is evidence of fishing tools from these sites, including hooks made from bird forelimbs and bone needles for sewing nets (Daugnora and Girininkas, 1995; Rimantienè, 2005; Girininkas and Daugnora, 2015), there have been no analyses of fish bone remains from the Kretuonas sites until this present study. Fish bone samples from all sites were morphologically identified where possible before being sent to the University of Manchester for ZooMS collagen fingerprint analysis. 


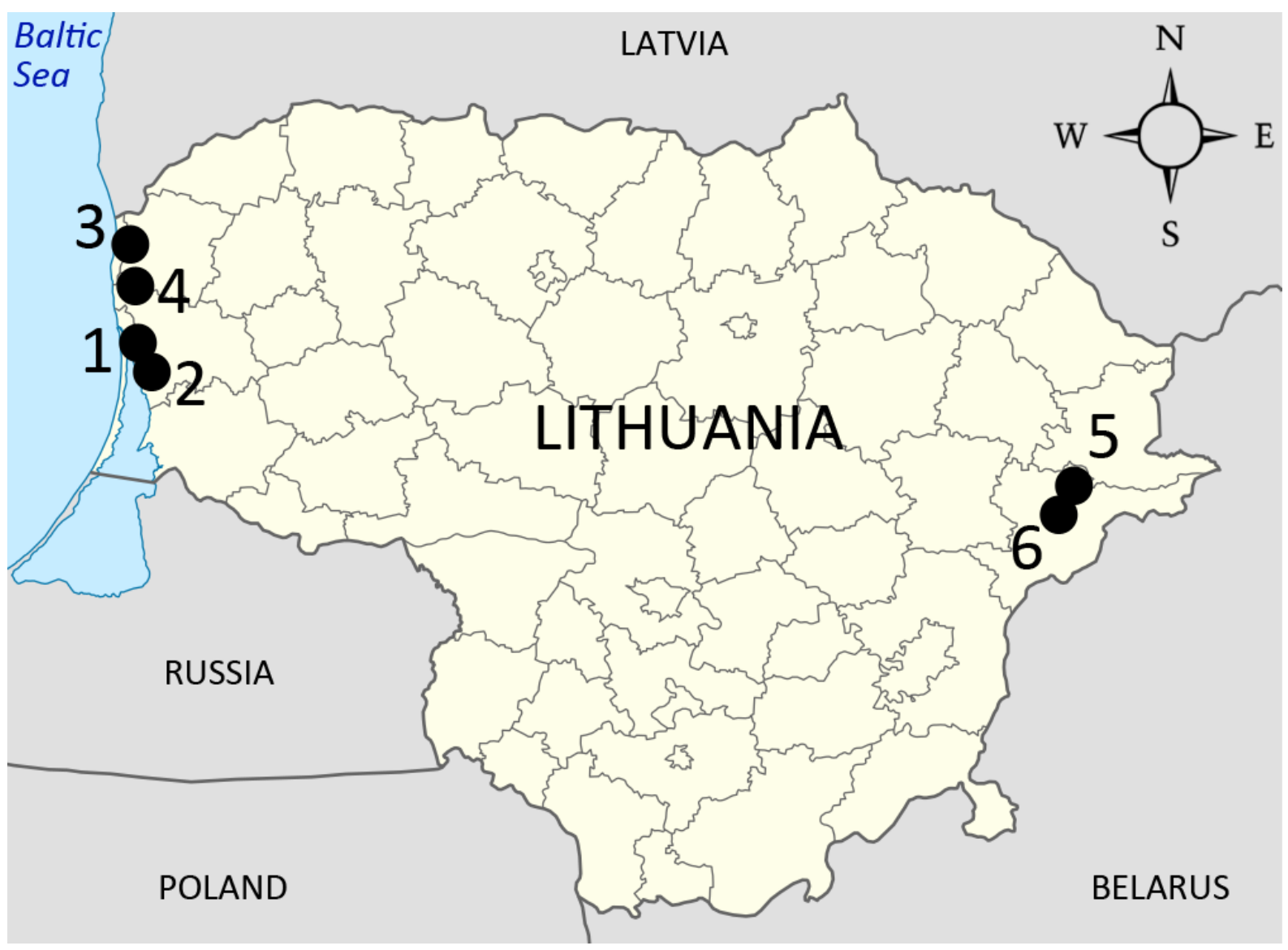

Figure 1: Map showing sample locations. (1) Klaipèda Castle; (2) Klaipėda City; (3) Šventoji 2B; (4) Šventoji 4A and 4B; (5) Kretuonas 1A; and (6) Kretuonas 1B. Image adapted from NordNordWest (Wikimedia Commons).

\subsection{Collagen Fingerprinting}

\subsubsection{Reference Material}

Modern bone samples were processed for acid-soluble and acid-insoluble ZooMS analysis following the methods adapted from Buckley et al. (2009) and van der Sluis et al. (2014) respectively. Here, skeletal samples from a selection of geographically and taxonomically relevant actinopterygian fish of 10 different orders and 15 different families (Supplementary Table S1), were decalcified in $1 \mathrm{~mL} 0.6 \mathrm{M}$ hydrochloric acid ( $\mathrm{HCl}$; Fisher Scientific, UK) at $4^{\circ} \mathrm{C}$ for $\sim 18 \mathrm{~h}$ to release acid-soluble collagen (I). Following demineralisation, two independent volumes of $500 \mu \mathrm{L} \mathrm{HCl}$ were transferred to $10 \mathrm{kDa}$ molecular weight cut off (MWCO) ultrafilters (Vivaspin, UK), centrifuging at $12,400 \times \mathrm{g}$ for $30 \mathrm{~min}$ between each volume to pass the supernatant through. Following each spin the ultrafilter through-flow was discarded and the filter washed with two separate volumes of $500 \mu \mathrm{L} 50 \mathrm{mM}$ ammonium bicarbonate (ABC; Sigma-Aldrich, UK) and centrifuged for $30 \mathrm{~min}$. Collagen was collected by dispensing and aspirating $100 \mu \mathrm{L} 50 \mathrm{mM} \mathrm{ABC}$ onto the filter $\sim 20$ times and transferring to a fresh Eppendorf tube. $0.4 \mu \mathrm{g}$ sequencing-grade trypsin (Promega, UK) was added to each sample and incubated at $37^{\circ} \mathrm{C}$ for $18 \mathrm{hr}$.

Following digestion, samples were purified and fractioned via reversed phase chromatography using C18 solid phase extraction (SPE) pipette tips (Varian, UK), following manufacturer's protocol, whereby each sample was acidified to a concentration of $0.1 \%$ trifluoroacetic acid (TFA; Signa-Aldrich, UK) and, to aid biomarker identification, eluted into two distinct fractions of increasing acetonitrile (ACN; Merck, UK) concentrations: $10 \%$ 
ACN/0.1\% TFA and 50\% ACN/0.1\% TFA. Fractions were air-dried for $48 \mathrm{hr}$ and resuspended with $10 \mu \mathrm{L} 0.1 \%$ TFA. $1 \mu \mathrm{L}$ was then spotted onto a Bruker mass spectrometer (MS) target plate and co-crystalised with $1 \mu \mathrm{L}$ of $\alpha$-cyano-4-hydroxycinnamic acid matrix solution $(0.1 \%$ TFA in ACN/ $\left.\mathrm{H}_{2} \mathrm{O} 1: 1 \mathrm{v} / \mathrm{v}\right)$. Spots were air-dried before being applied to a Bruker Ultraflex II MALDI-MS operating at 2000 laser shots per plate spot, over a $\mathrm{m} / \mathrm{z}$ range of $700-3700$. Calibration was achieved using a five-calibrant peptide spot of 0.9-3.7 kilodalton range, placed adjacent to sample spots. Original bone sample pellets were air-dried and stored at room temperature. Collagen fingerprints were analysed using mMass software (v5.5.0). (See Supplementary Figures S6.1-S6.34 for annotated collagen fingerprints of modern specimens, and Supplementary Table S3 for peak lists of modern representatives of the species found in the assemblage).

\subsubsection{Ancient Material}

A total of 114 fragments of fish bone from sites in Lithuania were analysed initially for soluble collagen (I). Each bone sample was placed in a $1.5 \mathrm{~mL}$ Eppendorf tube and $1 \mathrm{~mL}$ of $0.6 \mathrm{M} \mathrm{HCl}$ added prior to overnight demineralisation $\left(\sim 18 \mathrm{hr}, 4^{\circ} \mathrm{C}\right)$. Samples were centrifuged for $1 \mathrm{~min}$ at $12,400 \mathrm{xg}$ to precipitate the pellet and acid-soluble fractions were buffer exchanged into $50 \mathrm{mM} \mathrm{ABC}$ and digested using the same procedure as the modern samples (above). Ancient samples were then purified and concentrated with C18 SPE pipette tips into 10\% ACN/ 0.1\% TFA and 50\% ACN/0.1\% TFA fractions, then dried, resuspended and analysed using a Bruker Ultraflex II MALDI-MS operating at 2000 laser shots per plate spot $(\mathrm{m} / \mathrm{z}$ range $=700-3700$ ) (as above). Collagen fingerprints were analysed using mMass software (v5.5.0) and faunal identification was achieved through comparative analysis with reference fingerprints.

Samples that failed to produce a collagen signal during mass spectrometric analysis of the concentrated $10 \%$ and $50 \%$ ACN fractions were subsequently analysed for their insoluble collagen (following Buckley et al., 2009). $300 \mu \mathrm{L} 50 \mathrm{mM} \mathrm{ABC}$ was applied to each bone pellet and samples were gelatinised at $75^{\circ} \mathrm{C}$ for $3 \mathrm{hr}$. Following gelatinisation, samples were centrifuged briefly and the supernatant removed and placed into a fresh Eppendorf tube. $0.4 \mu \mathrm{g}$ of trypsin was introduced to each sample before incubation at $37^{\circ} \mathrm{C}$ for $18 \mathrm{hr}$. Following digestion, samples were fractioned into two ACN concentrations ( $10 \%$ and $50 \%$ ) and analysed as above (see Supplementary Table S2 for all ancient sample identifications, Supplementary Figures S7.1-S7.11 for annotated collagen fingerprints and Supplementary Table S4 for peak lists of one example of each ancient species found in the assemblage).

\subsubsection{Liquid Chromatography Tandem Mass Spectrometry (LC-MS/MS)}

Reduction and alkylation steps were carried out on a sub-selection of the modern reference fish analysed for their collagen fingerprints, with taxa representing those that were morphologically identified in the ancient assemblage: Carassius carassius, Esox lucius, Gadus morhua, Sander lucioperca, Scophthalmus maximus, Scophthalmus rhombus, Salmo salar, Salmo trutta fario, Salmo trutta trutta and Silurus glanis. Here, fresh bone from each species was processed for both its soluble and insoluble collagen as above, except following the final rinse using $50 \mathrm{mM} A B C$ (prior to the addition of trypsin), samples were reduced and alkylated for LC-MS/MS analysis to assist with peptide interpretation. Reduction was achieved by adding $2.1 \mu \mathrm{L}$ of $100 \mathrm{mM}$ dithiothreitol (DTT) for every $50 \mu \mathrm{L}$ of sample volume (total volume $=100 \mu \mathrm{L}$ and $300 \mu \mathrm{L}$ for soluble and insoluble samples respectively), and resting at room temperature for $40 \mathrm{~min}$. Following this, $8.4 \mu \mathrm{L}$ of $100 \mathrm{mM}$ iodoacetamide (IAM) was added for every $50 \mu \mathrm{L}$ sample volume and placed in the dark at room temperature for 45 
min before repetition of the DTT step as above. Soluble and insoluble samples were incubated with $0.4 \mu \mathrm{g}$ trypsin for 18 hours at $37^{\circ} \mathrm{C}$, and then purified and fractioned using C18 SPE tips as above.

Fractions from the C18 SPE step were fully dried and the four samples for each species (soluble $10 \%$ and $50 \%$ plus insoluble $10 \%$ and $50 \%$ ) were combined by resuspending in $10 \mu \mathrm{L}$ $0.1 \%$ TFA and combining $2 \mu \mathrm{L}$ of each in a fresh $1.5 \mathrm{~mL}$ tube. Samples were dried in a fume hood and resuspended in $5 \%$ ACN $+0.1 \%$ formic acid (FA). Samples were then analysed using LC-MS/MS (Waters nanoAcquity UPLC system coupled to a Thermo Scientific Orbitrap Elite MS) at the Biological Mass Spectrometry Core Research Facility (University of Manchester) similar to methods described in Buckley et al. (2015). Samples were concentrated on a $20 \mathrm{~mm} \times 180 \mu \mathrm{m}$ pre-column prior to being separated on a $1.7 \mu \mathrm{M}$ Waters nanoAcquity Ethylene Bridged Hybrid (BEH) C18 analytical column of $(75 \mathrm{~mm} \times 250$ $\mu \mathrm{m}$ i.d.). Fractionation was achieved using a gradient beginning at $99 \%$ buffer $A / 1 \%$ buffer $B$ and finishing at $75 \%$ buffer $A / 25 \%$ buffer $B$, whereby buffer $A=0.1 \% F A$ in $\mathrm{H}_{2} \mathrm{O}$ and buffer $B$ $=0.1 \%$ FA in ACN.

Resulting MS/MS datafiles (.mgf) were searched against publically available curated protein sequence database, SWISS-PROT, to check they contained the collagen (I) protein predominantly, before undergoing standard searches against a custom (local) database of fish collagen (I) sequences compiled using MASCOT (v2.5.1; Perkins et al., 1999). Datafiles were searched using standard 'decoy' searches to interrogate ion fragmentation matches using the strict criteria as follows: up to two missed cleavages, peptide tolerance of $\pm 5 \mathrm{ppm}$, MS/MS fragment ion mass value tolerance of $0.5 \mathrm{Da}$, a fixed carbamidomethyl modification of cysteine (mass shift $=+57.02 \mathrm{Da}$ ), variable deamidation of asparagine $(\mathrm{N})$ and glutamine (Q) modifications (mass shift $=+0.98 \mathrm{Da}$; to allow for common diagenetic alterations), and variable oxidation of methionine $(M)$, and hydroxylation of proline $(P)$ and lysine $(K)$ modifications (mass shift $=+15.99 \mathrm{Da}$; equivalent mass to the process of hydroxylation). To enable MASCOT to identify single amino acid sequence disparities in any one peptide, 'error tolerance' searches were employed using the criteria as follows: fixed carbamidomethyl modification of cysteine (mass shift $=+57.02 \mathrm{Da}$ ), variable modifications for the oxidation of lysine $(\mathrm{K})$ and proline $(\mathrm{P})$ and an allowance of one missed cleavage.

MASCOT search results were compared to the collagen fingerprints to identify peptides that could be assigned to a specific taxonomic level. Peaks that can be seen to differ between species following fingerprint interrogation were manually examined on the MASCOT search results for quality. Quality was defined by MASCOT-assigned ion scores, which were required to be higher than the highest false positive result, and the assessment of the fragment ion spectra. Where a high-scoring peptide sequence was found to be visible in the fingerprint for that species, the peptide was recorded as a biomarker for the taxon.

The mass spectrometry proteomics data have been deposited to the ProteomeXchange Consortium via the PRIDE partner repository with the dataset identifier PXD010041 (Vizcaíno et al., 2016).

\section{Results and Discussion}

\subsection{Species Identification using Collagen Fingerprinting}

Initial taxonomic identification was achieved through comparative analysis of ancient and reference material collagen fingerprints (Supplementary Table S2-S4, Figures S6-S7). Fingerprints were interrogated to see whether there were any peptide peak position 
disparities along the $m / z$ axis between the ancient spectra and the reference spectra they matched to. Fingerprints that could be matched to a reference specimen were assigned that identity. In cases where no other species within the genus are known to occur in the Baltic Sea (e.g. Esox lucius, the Northern pike; Figure 2), identification to species-level could be assigned with much greater confidence. In this particular case, no other species would be expected in the assemblage, even within the wider family group of Esocidae.

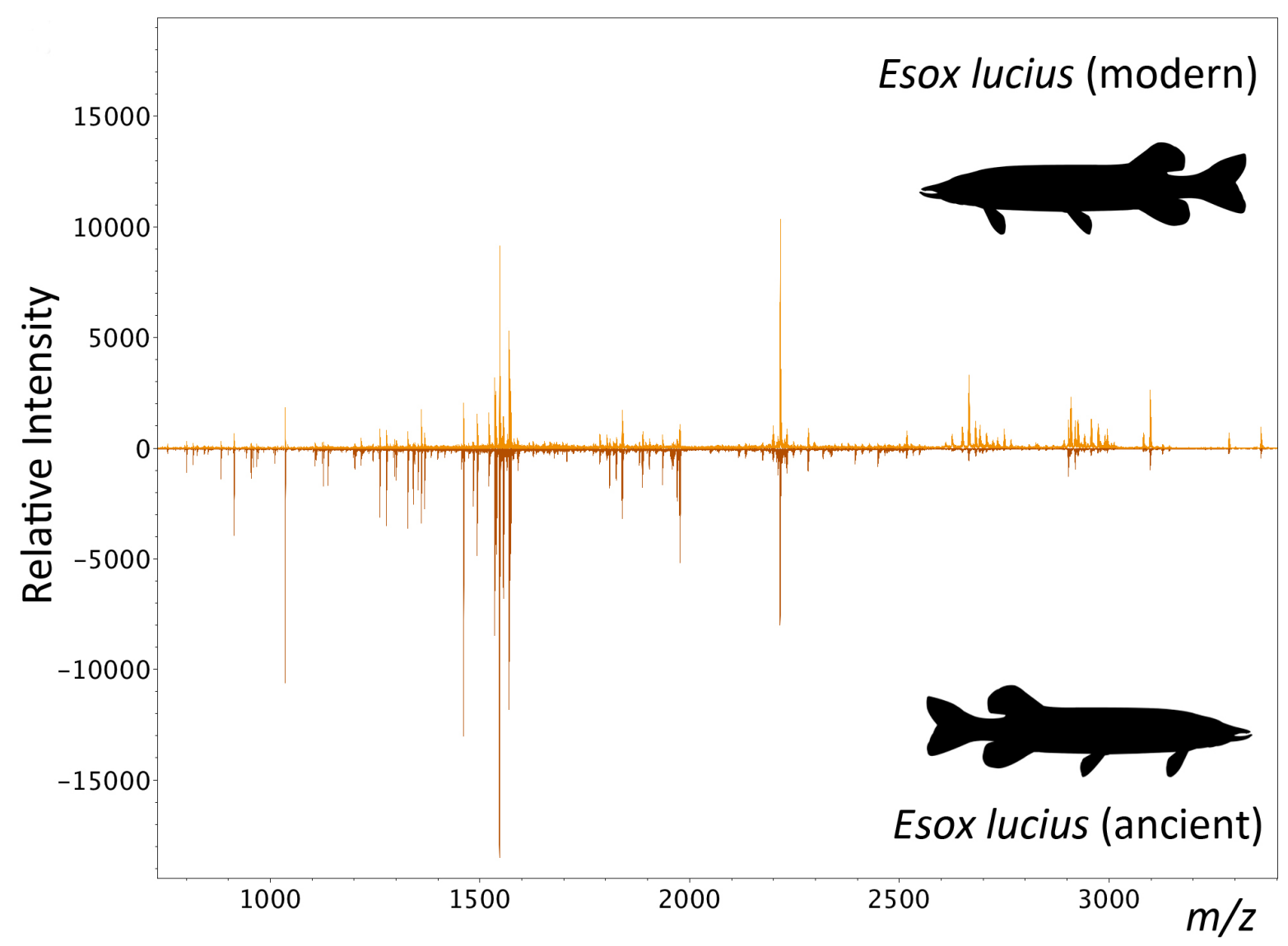

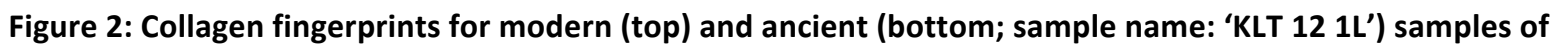
Northern pike, Esox lucius showing identical peak positions across the $m / z$ axis.

To achieve reliable refinement of identity to species-level where two or more members of the same genus are known in a locality, collagen fingerprint interrogation was combined with LC-MS/MS data to resolve species-specific peptide biomarkers. For example, two definitive amino acid sequence disparities are visible between the modern reference samples of Salmo salar (Atlantic salmon) and Salmo trutta (brown trout) (divergence time 10 Ma; Robertson et al., 2017) (Figure 3). 


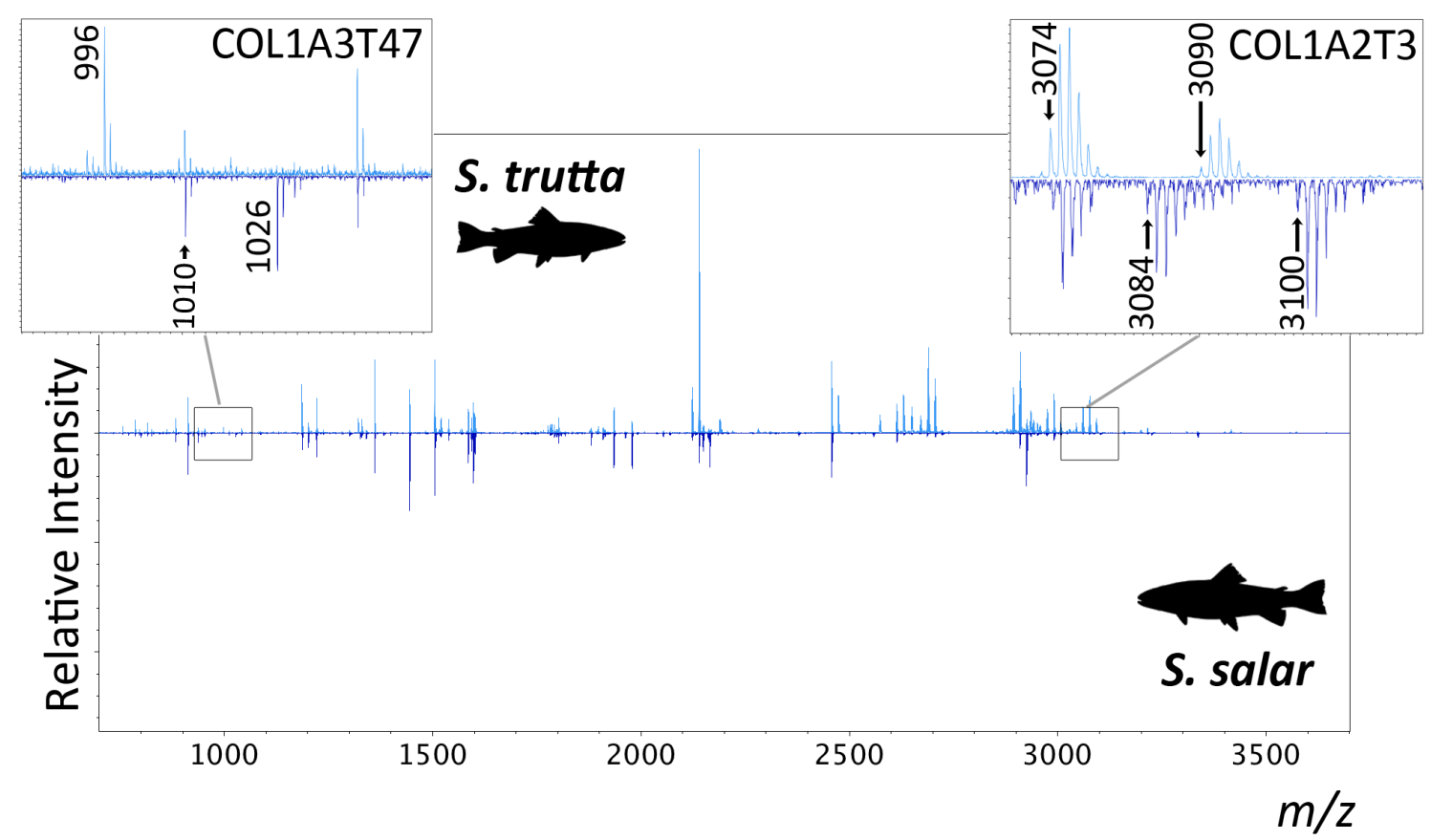

Figure 3: Collagen fingerprints from reference specimens of $S$. trutta (top) and S. salar (bottom) following tryptic digestion and purification with C18 SPE tips. Insets: Two peptide biomarkers are visible that distinguish the two species: Left inset-proposed $\alpha 3$ peptide COL1A3T47 at $\mathrm{m} / \mathrm{z} 996$ and $\mathrm{m} / \mathrm{z}$ 1026; and right inset-COL1A2T3 at $\mathrm{m} / \mathrm{z} 3074 / 3090$ and $\mathrm{m} / \mathrm{z} 3084 / 3100$ in $S$. trutta and $S$. salar respectively.

The lower mass biomarker (Figure 3) is present at $m / z 996$ (GGIGSAGPAGPR) in S. trutta and $\mathrm{m} / z 1026$ (GGIGSAGPTGPR) in S. salar. A protein BLAST (Basic Local Alignment Search Tool) search of the sequence in S. trutta matches it to collagen I tryptic peptide 47 on the $\alpha 3$ chain of closely related salmonid Oncorhynchus mykiss (BLAST Accession NP_001117678; Saito et al., 2001), but also to tryptic peptide 47 on the $\alpha 1$ chain of $O$. kisutch (Accession XP_020316038). Understanding whether the peptide belongs to the $\alpha 1$ or $\alpha 3$ chain can thus be better understood through the process of elimination. Specifically, the LC-MS/MS data suggests the peak visible at $m / z 1010$ in both $S$. trutta and $S$. salar represents tryptic peptide 47 of the $\alpha 1$ chain (GAPGPSGPAGAR), a sequence also listed on BLAST for $S$. salar (Accessions XP_014059932.1, XP_014048044), O. mykiss (XP_021413219) and Esox lucius (XP_010862194), the latter having diverged from the salmonids 105 million years ago (Ma) (Betancur-R et al., 2017). We therefore label the $m / z$ 996/1026 biomarker as COL1A3T47, referencing its proposed position on the $\alpha 3$ chain, in a labelling system defined by Buckley et al. (2009) and detailed by Buckley (2016) (Supplementary Figures S1-S3). The expression of the $\alpha 3$ chain has been previously recorded for O. mykiss (Saito et al., 2001), and the published genome of $S$. salar similarly shows the presence of the gene that codes for $\alpha 3$ (e.g. Martin et al., 2010). However, our data provides the first supporting evidence that peptides from the $\alpha 3$ chain can be visualised through collagen fingerprinting. The second biomarker, present at $\mathrm{m} / \mathrm{z}$ 3074/3090 in S. trutta (GPNGPPGSPGPQGFTGHAGEPGEPGQTGSIGAR) and $\mathrm{m} / z$ 3084/3100 in S. salar (GPNGPPGSPGPQGFTGHAGEPGEPGQTGPIGAR), is the third tryptic peptide from the $\alpha 2$ chain of the collagen molecule (COL1A2T3). The +16 peak shift that is visible here is due to the variable oxidation of proline (P) (Supplementary Figures S4-S5).

The two salmonids, S. trutta and S. salar diverged from each other approximately $10 \mathrm{Ma}$ (Robertson et al., 2017). Given the rate of sequence evolution in actinoptergiian fish is estimated at $\sim 1$ amino acid substitution every $1 \mathrm{Ma}$ across the entire molecule (Buckley, 2018), there are likely be more sequence disparities between these two species. However, the current publically available collagen (I) sequences for salmonids, though admittedly 
more abundant than for many other fish families, are not sufficient at this stage to infer further sequence changes. This is because some disparities are not always visible in the collagen fingerprint, which only typically displays around $40 \%$ of peptides (Buckley, 2016). It has not yet been possible to identify any collagen fingerprint disparities between the oceanic (Salmo trutta trutta) and the riverine sub-species of brown trout (S. trutta fario). This is unsurprising as the sub-species diverged from one another in the order of 450-700 Ka (Bernatchez et al., 1992), which is a timeframe not theoretically long enough for a collagen (I) amino acid substitution to have occurred (Buckley, 2018).

In addition to the salmonids, one species-specific homologous biomarker is visible between the two investigated members of the Pleuronectiformes, Scophthalmus rhombus (brill) and S. maximus (turbot) (Figure 4). Due to a poor representation of the Pleuronectiformes in the custom database and on BLAST (two species), and the absence of a published collagen (I) sequence from any scophthalmid, the two forms of the peptide cannot yet be probabilitymatched to obtain sequence data. However, the biomarker present at $m / z$ 1223/1239 was able to verify the identity of the species present in the ancient assemblage, whereby all samples display this peptide at $m / z 1239$ indicating that they are $S$. rhombus.

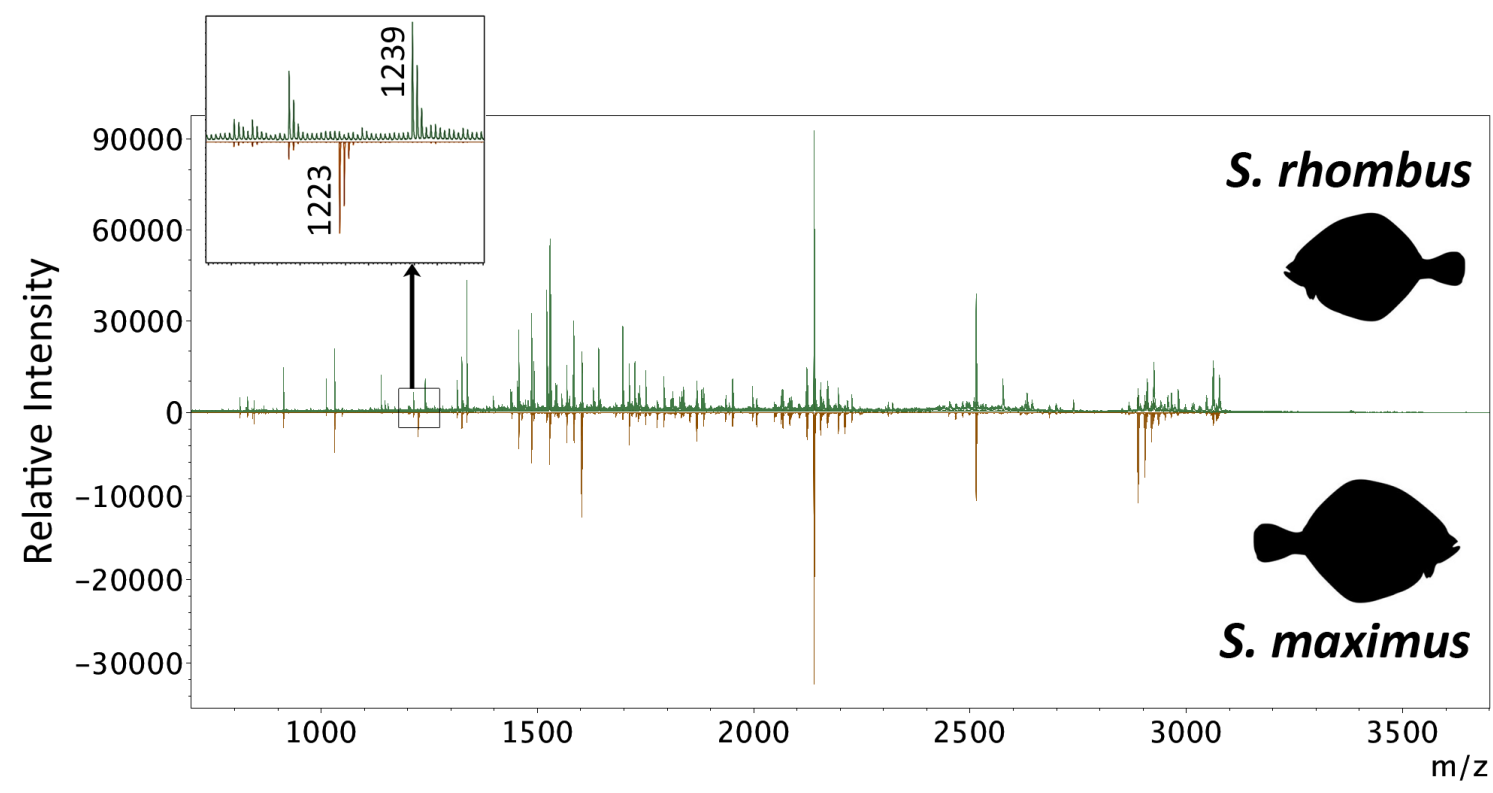

Figure 4: Collagen fingerprints from reference specimens of S. rhombus (top) and S. maximus (bottom) following tryptic digestion and purification with C18 SPE tips.

\subsection{Species Biomarkers for Fish}

Owing to the complexity of fish collagen, itself a consequence of rapid sequence evolution plus the added intricacy of the species- and tissue-specific $\alpha 3$ chain, collagen fingerprint taxonomic biomarkers for fishes are complex to define and have subsequently never been done so. Firstly, Richter et al. (2011) were able to separate species using principle component analysis (PCA) but did not attempt to identify any specific collagen biomarkers. Secondly, an overview of fish collagen by Buckley (2018) hinted at the complexity of the task by displaying a collagen fingerprint of $G$. morhua and closely related haddock, Melanogrammus aeglefinus, and labelling a selection of the most abundant peaks in each. However, whether or not the markers were homologous between the two species was not discussed. Here, we display for the first time a suite of homologous biomarkers across the various orders of taxa in this study, including Cypriniformes, Perciformes, Gadiformes, Esociformes, Salmoniformes, Pleuronectiformes and Siluriformes (Table 1). 


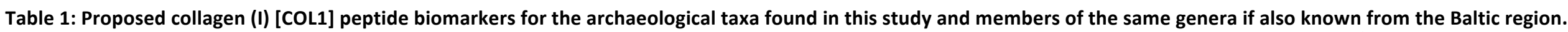
$\checkmark=$ peptide is present at this $m / z$ in the collagen fingerprint for this species; X=peptide code unknown. Peptide code previously published for other taxa in: ${ }^{1}$ Buckley et al. (2014); ${ }^{2}$ Buckley et al. (2009).

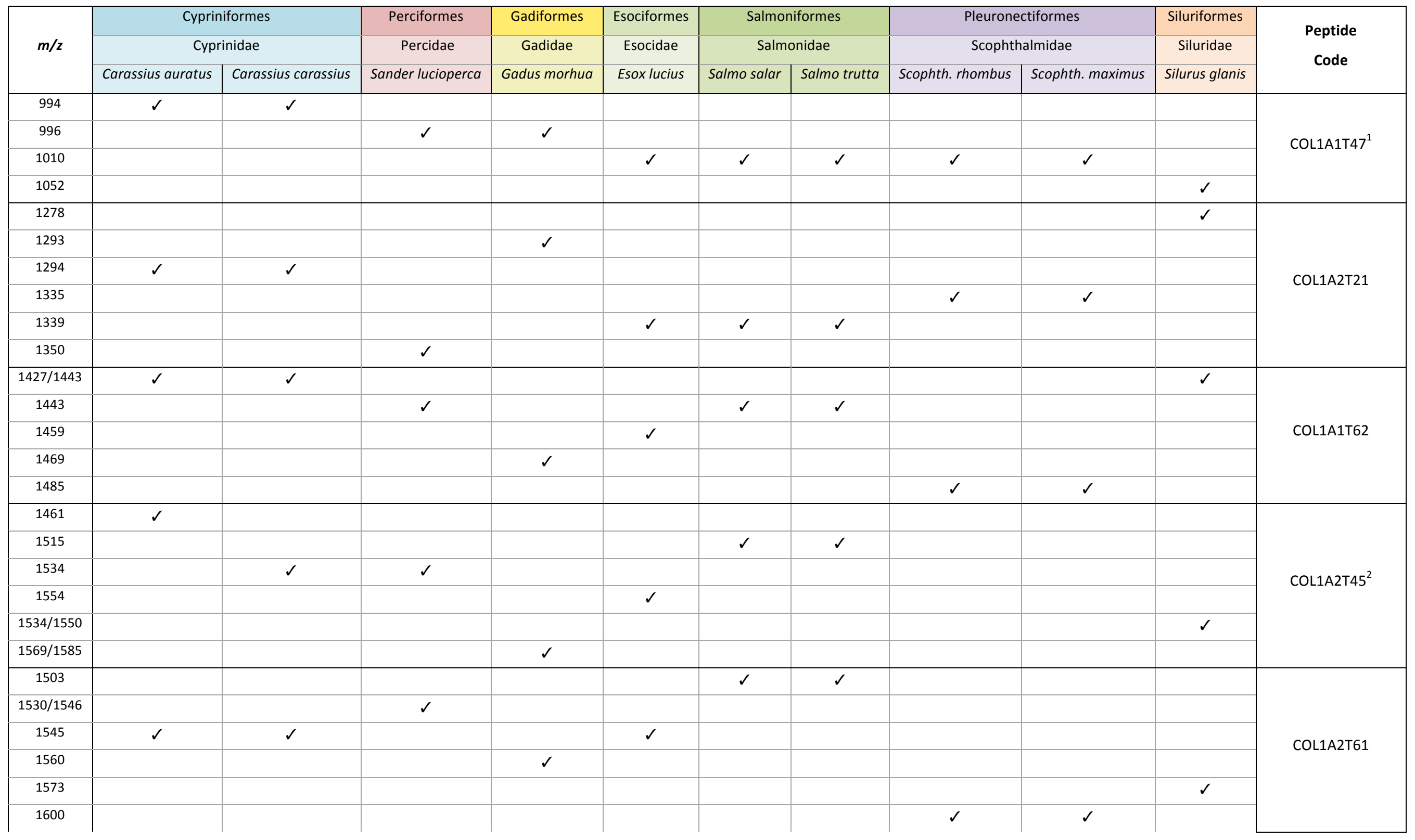




\begin{tabular}{|c|c|c|c|c|c|c|c|c|c|c|c|}
\hline 1766/1782 & & & & $s$ & & & & & & & \multirow{7}{*}{ COL1A1T73 } \\
\hline 1774/1790 & & & & & & $s$ & $s$ & $s$ & $\checkmark$ & & \\
\hline $1784 / 1800$ & & & & & 2 & & & & & & \\
\hline 1790/1806 & & & $s$ & & & & & & & & \\
\hline 1796/1812 & & & & & & & & & & $s$ & \\
\hline 1816/1832 & & $s$ & & & & & & & & & \\
\hline 1826/1842 & $\checkmark$ & & & & & & & & & & \\
\hline 2065 & & & & & & & & & & 2 & \multirow{7}{*}{ COL1A2T56 } \\
\hline 2083 & & & & $\checkmark$ & & & & & & & \\
\hline 2100 & & & $s$ & & & & & & & & \\
\hline 2137 & & & & & & $\checkmark$ & $s$ & $s$ & $\checkmark$ & & \\
\hline 2138 & & $\checkmark$ & & & & & & & & & \\
\hline 2170 & $s$ & & & & & & & & & & \\
\hline 2213 & & & & & $s$ & & & & & & \\
\hline $2612 / 2628$ & & & & & & $\checkmark$ & 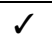 & & & & \multirow{6}{*}{ COL1A1T85 } \\
\hline $2663 / 2679$ & & & & & $s$ & & & & & & \\
\hline 2665/2681 & & & & & & & & $s$ & $\checkmark$ & & \\
\hline 2670/2686 & & & & $\checkmark$ & & & & & & & \\
\hline $2674 / 2690$ & $s$ & $s$ & & & & & & & & & \\
\hline 2690/2706 & & & & & & & & & & $s$ & \\
\hline $1186+898$ & & & & $\checkmark$ & & & & & & & \multirow{6}{*}{ COL1A2T69 $(1)+(2)^{2}$} \\
\hline $1200+894$ & $s$ & & & & & & & & & & \\
\hline $1220+882$ & & & & & & $s$ & $\checkmark$ & & & & \\
\hline $1260+882$ & & & & & $\checkmark$ & & & & & & \\
\hline $1262+910$ & & $s$ & & & & & & & & & \\
\hline $1269+910$ & & & & & & & & & & $\checkmark$ & \\
\hline 3074/3090 & & & & & & & $s$ & & & & \multirow{2}{*}{ COL1A2T3 } \\
\hline 3084/3100 & & & & & & $s$ & & & & & \\
\hline 996 & & & & & & & $\checkmark$ & & & & \multirow{3}{*}{ COL1A3T47 } \\
\hline 1026 & & & & & & $s$ & & & & & \\
\hline 1083 & & & & $\checkmark$ & & & & & & & \\
\hline 1223 & & & & & & & & & $\checkmark$ & & \multirow{2}{*}{$\mathrm{x}$} \\
\hline 1239 & & & & & & & & 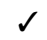 & & & \\
\hline
\end{tabular}


Collagen biomarkers have been widely published for mammals (e.g. Buckley et al., 2016), birds (e.g. Buckley et al., 2009), and more recently for reptiles and amphibians (Buckley, 2018). Collagen (I) biomarkers presented by the pioneering work on ZooMS (Buckley et al., 2009), were originally investigated because they were amongst the least conserved (i.e. most rapidly evolving) regions of the collagen (I) molecule in the taxa interrogated (mammal and bird representatives), in addition to the fact that they generated the most abundant signals. These regions display higher rates of inter-specific variation, and thus provide a key service when distinguishing between closely related vertebrate species. However, in fish, many of these regions of the collagen molecule are so quick to evolve that they are too diverse to be matched to [currently available] collagen sequences. In such cases, both the homologous peptide peaks (MS analysis) and peptide sequences (MS/MS analysis) will remain unidentified between species and can therefore play only minimal roles in species identification. Further to this, arginine $(R)$ and lysine $(K)$ residues (the $C$-terminals of which are active trypsin sites), are sometimes substituted into collagen sequences in place of nontryptic residues, causing a peptide biomarker that may be diagnostically useful in some vertebrate clades to be cleaved into two separate, smaller peptides in fish. For example, peptide COL1A2T69 (peptide 'D' following nomenclature in Buckley et al., 2009), can be used to distinguish a suite of vertebrate species, including being vital for separating narwhals from beluga whales (Buckley et al., 2014). However, in the majority of fish species that have available collagen sequences this $D$ marker is cleaved into two separate peptides during tryptic digests [here we label these COL1A2T69 (1) and (2) to maintain homolog comparison with other vertebrate clades]. Furthermore, each of these two peptides are typically so diverse that even members of the same genus (e.g. Carassius carassius and $C$. auratus) have different sequences for both (Table 1).

It is also worth noting here that some peptides of the identical $m / z$ in Table 1 are isobaric to one another but may have very different amino acid sequences, including peptide COL1A2T56 at $\mathrm{m} / \mathrm{z} 2137$ in scophthalmids (GEVGPAGAPGFAGPPGADGQPGAR) and also in salmonids (GEGGPAGPPGFAGPPGSDGQSGPR).

\subsection{Assemblage Composition}

Of the 114 samples, 85 (75\%) have generated collagen (I) peptide mass fingerprints that are suitable for inferring taxonomic identity (Table 2; Figure 5). Such identities confirm the presence of eleven species, including at least 3 different species of cyprinid (family Cyprinidae) and one perciform (order Perciformes) (Supplementary Table S2). All of the samples from Kretuonas $1 \mathrm{~A}$ and $1 \mathrm{~B}$ failed to generate a collagen signal (see Harvey et al., 2016 for the definition of a failed collagen fingerprint). It is possible that the samples collected from the Kretuonas sites have been charred from cooking practices, which correlates to the dark grey colour of these bone samples in comparison to those from the western sites. The only samples not yet identified to species level are the cyprinids (three forms) and perciform (one form). This is not a factor of the quality of the collagen fingerprints, but rather it is a limitation of the current reference collection. These samples are highly likely to be refinable to species-level if the correct reference taxa can be obtained, although with at least 20 perciform and 26 cyprinid species known to Lithuanian waters (Froese and Pauly, 2017), the task is beyond the scope of this present study. 
Table 2: The number of ZooMS-derived fish identifications for each site featured in this study. Figures relate to the number of identified specimens (NISP).

\begin{tabular}{|c|c|c|c|c|c|c|c|c|c|c|c|}
\hline Site & $\begin{array}{l}\text { Carassius } \\
\text { carassius }\end{array}$ & $\begin{array}{l}\text { Esox } \\
\text { lucius }\end{array}$ & $\begin{array}{c}\text { Gadus } \\
\text { morhua }\end{array}$ & $\begin{array}{l}\text { Salmo } \\
\text { trutta }\end{array}$ & $\begin{array}{l}\text { Scophthal } \\
\text { mus } \\
\text { rhombus }\end{array}$ & $\begin{array}{c}\text { Sander } \\
\text { lucioperca }\end{array}$ & $\begin{array}{c}\text { Silurus } \\
\text { glanis }\end{array}$ & $\begin{array}{l}\text { Cyprin } \\
\text { idae }\end{array}$ & $\begin{array}{c}\text { Perci } \\
\text { formes }\end{array}$ & Poor & Total \\
\hline Klaipèda Castle & 1 & & & & & & & 4 & 1 & & 6 \\
\hline Klaipèda City & & 1 & 1 & & & 4 & & & & & 6 \\
\hline Šventoji 2B & & 13 & & & 2 & 10 & 8 & & & & 33 \\
\hline Šventoji 4A & 13 & 8 & 1 & & 9 & 3 & 1 & 1 & & & 36 \\
\hline Šventoji 4B & & 2 & & 1 & & & 1 & & & & 4 \\
\hline Kretuonas $1 \mathrm{~A}$ & & & & & & & & & & 20 & 20 \\
\hline Kretuonas 1B & & & & & & & & & & 9 & 9 \\
\hline Total & 14 & 24 & 2 & 1 & 11 & 17 & 10 & 5 & 1 & 29 & 114 \\
\hline
\end{tabular}

The most abundant species in the identified assemblage is the northern pike, E. lucius. Consequently the majority of the species are typically freshwater/brackish-dwelling in the Baltic region (83\%), also including C. carassius, Silurus glanis, Sander lucioperca and the cyprinid forms. The species that are more characteristic of marine/brackish environments, $G$. morhua and S. rhombus, comprise $15 \%$ of the assemblage. We note that the single perciform cannot as yet be defined by habitat as both marine and freshwater species are present in the Baltic. Finally, one specimen of $S$. trutta is present which could be either the freshwater (S. trutta fario) or marine (S. trutta trutta) ecotype (Figure 5).

The relative proportions of freshwater/brackish (83\%) and marine/brackish (15\%) species found at the Neolithic Šventoji sites are in keeping with the literature, where freshwater fishing environments were generally favoured by the Neolithic communities, but with increasing influence of marine species into the Late Neolithic and beyond (Makowiecki, 2003; Daugnora and Girininkas, 2004). At the medieval Klaipeda sites, there was a presence of just one marine specimen, $\operatorname{cod}(G$. morhua), compared to ten samples of freshwater/brackish origin. Here, an increased quantity of marine/brackish specimens would have been expected due to reports of a reduction in freshwater fish stocks during these times in medieval Europe (Barrett et al., 2011; Lotze et al., 2014). However, with such a small sample size for the medieval sites this trend should be looked at with caution. 


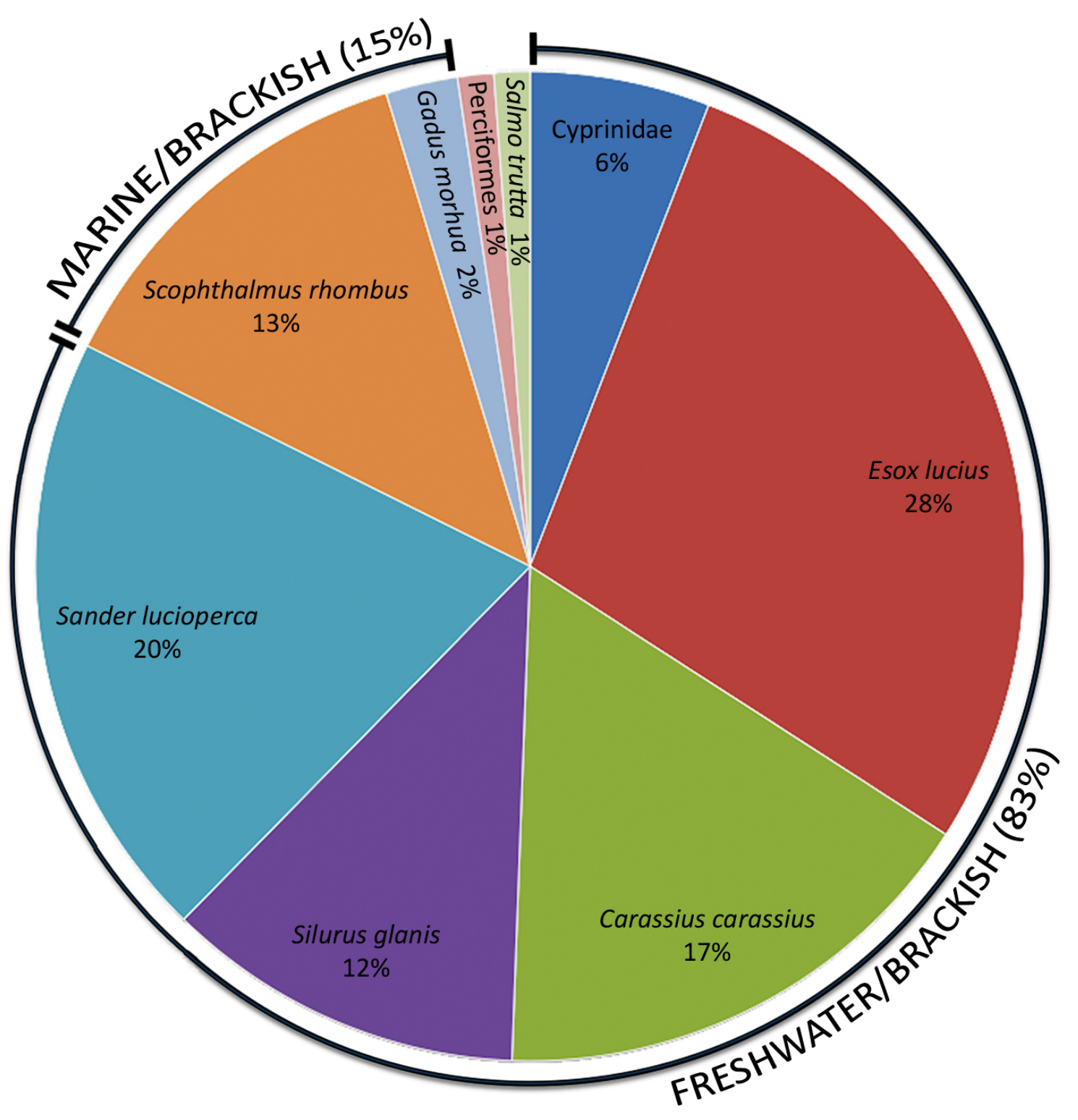

Figure 5: Assemblage composition: chart showing the relative abundance (\%) of fish species found through ZooMS-derived identifications of archaeological fish bone from Lithuania (calculated from NISP, Table 2). Salinity categories assigned following (Froese and Pauly, 2017).

Both assemblage composition and habitat distribution across marine and freshwater systems are similar to those presented by Stančikaitè et al. (2009) when morphologically identifying fish bones from Šventoji 4A. Stančikaitè et al. (2009) found the majority of samples to be $E$. lucius and also reported a dominance of freshwater/brackish species. Our study shows slightly higher proportions of freshwater/brackish species and the analysis has unpicked and expanded categories into more precise groups. For example, Stančikaitè et al. (2009) bundled carp (C. carassius) and all other cyprinids into the category 'minnows' whereas collagen fingerprinting has allowed the separation of this group into the crucian carp, $C$. carassius, and all other cyprinids. Similarly, 'flounders' was used as a collective term for up to five different Pleuronectiform species, whereas this study verifies the presence of just one species, S. rhombus. 


\subsection{Molecular Versus Morphological Identification}

All samples were morphologically identified where possible, before ZooMS collagen fingerprinting was applied (Supplementary Table S2). A total of $84 \%(n=71)$ of all successfully fingerprinted samples that were morphologically assigned an identity had been correctly identified. However, ZooMS was able to refine the taxonomic identification in $34 \%$ $(n=24)$ of these samples from family-level 'Cyprinidae' and 'Pleuronectidae' to species-level 'Carassius carassius' and 'Scophthalmus rhombus' respectively. Additionally, two samples were morphologically identified as either 'Gadus morhua/Sander lucioperca' and ZooMS analysis was able to confirm these identities as S. lucioperca. A total of $7 \%$ of the successfully fingerprinted samples had been incorrectly morphologically identified and the most common identity incorrectly assigned was Salmo salar, to a total of four samples. Yet, this species does not occur in the assemblage at all and instead these samples have been molecularly identified as E. Iucius $(n=2)$, Silurus glanis $(n=1)$ and Salmo trutta $(n=1)$. As an intentional component of this study, 27 samples were included because they could not be assigned morphological identifications. Interestingly, 19 (70\%) of these also failed collagen fingerprinting (the majority of samples being from the Kretuonas sites) highlighting a potential correlation between physical and molecular preservation. One of the remaining eight is a perciform and seven are cyprinids, with the identity of three being refined to species-level as the crucian carp, $C$. carassius.

\subsection{Ecological Understanding}

Throughout the time of human settlement in coastal Lithuania, the Baltic area has undergone freshwater, brackish and marine phases, and these changes in salinity have dictated the fish species available for catch. Collagen analysis methods of species identification on ancient deposited bone show that fish harvested from the Baltic Sea following the maximal Littorina Sea transgression in two different timeframes, $\sim 500 \mathrm{yr} B P$ (Klaipeda sites) and $\sim 6000$ yr BP (Šventoji sites), comprise a rich composition of both freshwater (the majority) and marine representatives. All the species identified in this study have been recorded as still present in the most recent Baltic species checklist covering the Lithuanian coast (see 'Eastern Gotland Basin' region in HELCOM, 2012), however, three species, C. carassius, Silurus glanis and Scophthalmus rhombus are listed as exhibiting only a 'temporary occurrence' in these waters today. Additionally, only G. morhua is understood to be regularly reproducing in these waters presently, with all other species found in this study, E. lucius, Salmo trutta and Sander lucioperca, occurring regularly but with no signs of reproduction. Baseline species distribution and biological composition data (i.e. levels before the onset of modern-day intensive fishing) cannot be so easily concatenated from either biological checklists (the HELCOM checklist of Baltic Sea Species was founded in 2009) or modern [often under-reported] fisheries data (e.g. Zeller et al., 2011) and this 'shortfall' must therefore be constructed through other means, such as zooarchaeological analysis. Considering catch monitoring for the Baltic Sea commenced in just 1903, with datasets remaining largely fragmentary until 1950, and with Lithuania submitting independent fisheries data from just 1988 (ICES Catch Statistic Database), baseline data that is used presently to inform modern management is likely to be vastly underestimated. For example, fisheries data for the whole of the Baltic Sea declares no reported landings of $C$. carassius until 1974 or S. glanis until 2006 by any of the countries that have historically harvested its waters (ICES Catch Statistic Database), yet this present study highlights these species as having been exploited 6000 years ago. Though these observations do not take into account 
social and cultural differences that can dictate dietary preferences through time, it is highly likely that current fisheries baseline data is misrepresented-a concern also noted widely in the literature for both the Baltic Sea (MacKenzie et al., 2002), and beyond (Pauly, 1995; Pinnegar and Engelhard, 2008). As morphological analysis does not provide access to entire assemblages and is no longer a novel technique for the Baltic region (e.g. Stančikaite et al., 2009), molecular species identification of ancient refuse piles is a valuable technique that we show here as being more accurate than morphological identification, whilst carrying the capacity to complement modern fisheries data, expose species distributions and biological compositions and rewrite baselines.

\section{Conclusions}

ZooMS collagen fingerprinting and LC-MS/MS are pivotal analytical techniques in proteomics, proficient in uncovering precise taxonomic identity (to species-level) and assemblage composition information in ichthyoarchaeological remains up to $\sim 6000$ years old from the Baltic region. As well as uncovering mistakes made in morphological identification, this molecular toolset allows the visualisation of fisheries data prior to modern era datasets, which commonly neglect to capture the full extent of anthropogenic aquatic harvesting. Our hope is that ZooMS collagen fingerprinting will continue to be used in archaeological contexts to help improve baseline fisheries data, inform decision makers and increase environmental protection for the benefit of all stakeholder groups.

\section{Acknowledgements}

We wish to gratefully acknowledge the Biological Mass Spectrometry Core Research Facility at the University of Manchester for access to their facilities. Many thanks also go to Umberto Albarella and Angelos Hadjikoumis of the University of Sheffield, Dr. Hannah Russ of University of Wales Trinity Saint David, Creswell Crags Museum and Holly Shiels laboratory at the University of Manchester for assisting with the provisions of modern reference material for comparative analyses. We are also deeply grateful to Rimute Rimantienè, Edvinas Ubis, Gintautas Zabiela and Algirdas Girininkas for their roles in excavating the bioarcheological material analysed in this study. Finally, we gratefully acknowledge the support of the Royal Society for fellowship (UF120473) funding to MB as well as the University of Manchester Dean's Award for scholarship funding to VH.

\section{References}

Andrén E, Andrén T and Sohlenius G. (2000) The Holocene history of the southwestern Baltic Sea as reflected in a sediment core from the Bornholm Basin. Boreas 29: 233-250.

Andrén T, Björck S, Andrén E, et al. (2011) The development of the Baltic Sea Basin during the last 130 Ka. In: Harff J. BS, Hoth P. (ed) The Baltic Sea Basin. Berlin: Springer, 7597.

Barrett JH, Orton D, Johnstone C, et al. (2011) Interpreting the expansion of sea fishing in medieval Europe using stable isotope analysis of archaeological cod bones. Journal of Archaeological Science 38: 1516-1524.

Bernatchez L, Guyomard R and Bonhomme F. (1992) DNA sequence variation of the mitochondrial control region among geographically and morphologically remote European brown trout Salmo trutta populations. Molecular Ecology 1: 161-173.

Betancur-R R, Wiley EO, Arratia G, et al. (2017) Phylogenetic classification of bony fishes. BMC Evolutionary Biology 17: 162. 
Buckley M. (2013) A molecular phylogeny of Plesiorycteropus reassigns the extinct mammalian order 'Bibymalagasia'. PLoS One 8: e59614.

Buckley M. (2016) Species identification of bovine, ovine and porcine type 1 collagen; comparing peptide mass fingerprinting and LC-based proteomics methods. International Journal of Molecular Sciences 17: 445.

Buckley M. (2018) Zooarchaeology by Mass Spectrometry (ZooMS) Collagen Fingerprinting for the Species Identification of Archaeological Bone Fragments. In: Giovas C. LM (ed) Zooarchaeology in Practice. Cham: Springer.

Buckley M, Collins M, Thomas-Oates J, et al. (2009) Species identification by analysis of bone collagen using matrix-assisted laser desorption/ionisation time-of-flight mass spectrometry. Rapid Communications in Mass Spectrometry 23: 3843-3854.

Buckley M and Collins MJ. (2011) Collagen survival and its use for species identification in Holocene-lower Pleistocene bone fragments from British archaeological and paleontological sites. Antiqua 1: 1.

Buckley M, Fariña RA, Lawless C, et al. (2015) Collagen sequence analysis of the extinct giant ground sloths Lestodon and Megatherium. PLoS One 10: e0139611.

Buckley M, Fraser S, Herman J, et al. (2014) Species identification of archaeological marine mammals using collagen fingerprinting. Journal of Archaeological Science 41: 631641.

Buckley M, Gu M, Shameer S, et al. (2016) High-throughput collagen fingerprinting of intact microfaunal remains; a low-cost method for distinguishing between murine rodent bones. Rapid Communications in Mass Spectrometry 30: 1-8.

Buckley M, Harvey VL and Chamberlain AT. (2017) Species identification and decay assessment of Late Pleistocene fragmentary vertebrate remains from Pin Hole Cave (Creswell Crags, UK) using collagen fingerprinting. Boreas.

Buckley M, Larkin N and Collins M. (2011) Mammoth and Mastodon collagen sequences; survival and utility. Geochimica et Cosmochimica Acta 75: 2007-2016.

Damušytė A. (2011) Lietuvos pajūrio geologinè raida poledynmečiu. Daktaro disertacijos (Post-Glacial Geological History of the Lithuanian Coastal Area. Doctoral Dissertation). Vilnius: Vilniaus Universiteto Leidykla.

Daugnora L and Girininkas A. (1995) Analysis of faunal remains from the Kretuonas lake settlement. International Journal of Osteoarchaeology 5: 83-92.

Daugnora L and Girininkas A. (1996) Osteoarcheologija Lietuvoje: vidurinysis ir velyvasis holocenas, Vilnius: Savastis: Vilnius: Kultūros paveldo centras.

Daugnora L and Girininkas A. (1998) Stock breeding in the Baltic Culture area. Archaeologia Baltica 3: 223-234.

Daugnora L and Girininkas A. (2004) Rytụ Pabaltijo bendruomeniụ gyvensena XI-II tūkst. Pr. $K r$. (Subsistence economy of East Baltic communities in the 11-2 millennium BC): Lietuvos Veterinarijos Akademija, Kaunas.

Emeis K-C, Endler R, Struck U, et al. (2002) The post-glacial evolution of the Baltic Sea. In: Wefer G, Berger WH, Behre K-E, et al. (eds) Climate Development And History Of The North Atlantic Realm. Berlin: Springer, 205-221.

Enghoff IB. (1994) Fishing in Denmark during the Ertebølle periods. International Journal of Osteoarchaeology 4: 65-96.

Enghoff IB. (1999) Fishing in the Baltic Region from the 5th century BC to the 16th century AD: Evidence from Fish Bones. Archaeofauna 8: 41-85.

Froese R and Pauly D. (2017) FishBase. World Wide Web electronic publication. Home page at: http://www.fishbase.org (06/2017).

Gaumiga R, Karlsons G, Uzars D, et al. (2007) Gulf of Riga (Baltic Sea) fisheries in the late 17th century. Fisheries Research 87: 120-125. 
Girininkas A and Daugnora L. (2015) Ūkis ir visuomené Lietuvos priešistorèje, T. 1: Klaipèda: Klaipèdos Universiteto Leidykla.

Girininkas A and Žulkus V. (2017) Baltijos jūros krantai ir žmonės ankstyvajame Holocene. Jūros ir kranty tyrimai 2017, Klaipédos Universitetos: 69-72.

Gramsch B, Beran J, Hanik S, et al. (2013) A Palaeolithic fishhook made of ivory and the earliest fishhook tradition in Europe. Journal of Archaeological Science 40: 24582463.

Harff J, Lemke W, Lampe R, et al. (2007) The Baltic Sea Coast-A model of interrelations among geosphere, climate, and anthroposphere. In: Harff J, Hay WW and Tetzlaff DM (eds) Coastline Changes: Interrelation of Climate and Geological Processes. Boulder: Geological Society of America (Special Papers), 1-10.

Harvey VL, Egerton VM, Chamberlain AT, et al. (2016) Collagen fingerprinting: A new screening technique for radiocarbon dating ancient bone. PLoS One 11: e0150650.

HELCOM. (2012) Macrospecies Checklist for the Baltic Sea (http://www.helcom.fi/Lists/Publications/BSEP 130 FL.xlsx). Baltic Marine Environment Protection Commission (HELCOM).

HELCOM. (2017) The State of the Baltic Sea. Version 1. Baltic Marine Environment Protection Commission (HELCOM): 1-197.

Heron C, Craig OE, Luquin A, et al. (2015) Cooking fish and drinking milk? Patterns in pottery use in the southeastern Baltic, 3300-2400 cal BC. Journal of Archaeological Science 63: 33-43.

Holm P. (2016) Commercial Sea Fisheries in the Baltic Region c. ad 1000-1600. In: Barrett JH and Orton DC (eds) Cod and Herring: The Archaeology and History of Medieval Sea Fishing. Oxford: Oxbow Books, 13-22.

Jöns H. (2011) Settlement development in the shadow of coastal changes-Case studies from the Baltic Rim. The Baltic Sea Basin. New York, USA: Springer, 301-336.

Kadler KE, Holmes DF, Trotter JA, et al. (1996) Collagen fibril formation. Biochemical Journal 316: 1-11.

Limburg KE, Walther Y, Hong B, et al. (2008) Prehistoric versus modern Baltic Sea cod fisheries: selectivity across the millennia. Proceedings of the Royal Society of London B: Biological Sciences 275: 2659-2665.

Lotze HK, Hoffmann RC and Erlandson J. (2014) Lessons from historical ecology and management. In: Fogarty M and McCarthy J (eds) The Sea: Marine ecosystem-based management. Harvard University Press, 17-55.

Lõugas L. (1997) Post-glacial development of vertebrate fauna in Estonian water bodies. A palaeozoological study. Dissertationes Biologicae Universitatis Tartuensis 32: 1-79.

MacKenzie B, Awebro K, Bager M, et al. (2002) Baltic Sea fisheries in previous centuries: development of catch data series and preliminary interpretations of causes of fluctuations. ICES CM 50: 02.

MacKenzie BR, Bager M, Ojaveer H, et al. (2007) Multi-decadal scale variability in the eastern Baltic cod fishery 1550-1860-evidence and causes. Fisheries Research 87: 106-119.

Makowiecki D. (2003) Historia Ryb I Rybolówstwa W Holocenie Na Nizu Polskim W Swietle Badan Archeoichtiologicznych, Poznan: Instytut Archeologii i Etnologii Polskiej Akademii Nauk.

Martin SA, Douglas A, Houlihan DF, et al. (2010) Starvation alters the liver transcriptome of the innate immune response in Atlantic salmon (Salmo salar). BMC genomics 11: 418.

Meadows J, Eriksen BV, Zagorska I, et al. (2014) Dating Late Paleolithic Harpoons from Lake Lubāns, Latvia. Radiocarbon 56: 581-589. 
Mohrholz V, Naumann M, Nausch G, et al. (2015) Fresh oxygen for the Baltic Sea-An exceptional saline inflow after a decade of stagnation. Journal of Marine Systems 148: 152-166.

Morvan-Dubois G, Le Guellec D, Garrone R, et al. (2003) Phylogenetic analysis of vertebrate fibrillar collagen locates the position of zebrafish $\alpha 3$ (I) and suggests an evolutionary link between collagen $\alpha$ chains and Hox clusters. Journal of Molecular Evolution 57: 501-514.

Olson C and Walther Y. (2007) Neolithic cod (Gadus morhua) and herring (Clupea harengus) fisheries in the Baltic Sea, in the light of fine-mesh sieving: a comparative study of subfossil fishbone from the late Stone Age sites at Ajvide, Gotland, Sweden and Jettböle, Åland, Finland. Environmental Archaeology 12: 175-185.

Orton DC, Makowiecki D, de Roo T, et al. (2011) Stable isotope evidence for late medieval (14th-15th C) origins of the eastern Baltic cod (Gadus morhua) fishery. PLoS One 6: e27568.

Pauly D. (1995) Anecdotes and the shifting baseline syndrome of fisheries. Trends in Ecology \& Evolution 10: 430.

Perkins DN, Pappin DJ, Creasy DM, et al. (1999) Probability - based protein identification by searching sequence databases using mass spectrometry data. Electrophoresis 20: 3551-3567.

Piez KA. (1965) Characterization of a collagen from codfish skin containing three chromatographically different $\alpha$ chains. Biochemistry 4: 2590-2596.

Piličiauskas G, Luik H and Piličiauskienè G. (2015) Reconsidered Late Mesolithic and Early Neolithic of the Lithuanian coast: the Smelte and Palanga sites. Estonian Journal of Archaeology 19: 3-28.

Piličiauskas G, Mažeika J, Gaidamavičius A, et al. (2012) New archaeological, paleoenvironmental, and $14 \mathrm{C}$ data from the Šventoji Neolithic Sites, NW Lithuania. Radiocarbon 54: 1017-1031.

Pinnegar JK and Engelhard GH. (2008) The 'shifting baseline'phenomenon: a global perspective. Reviews in Fish Biology and Fisheries 18: 1-16.

Richter KK, Wilson J, Jones AK, et al. (2011) Fish'n chips: ZooMS peptide mass fingerprinting in a 96 well plate format to identify fish bone fragments. Journal of Archaeological Science 38: 1502-1510.

Rimantienè R. (1992a) Neolithic hunter-gatherers at Šventoji in Lithuania. Antiquity 66: 367376.

Rimantienè R. (1992b) The Neolithic of the eastern Baltic. Journal of World Prehistory 6: 97143.

Rimantienè R. (1996) Šventosios 4-oji radimvietè. Lietuvos Archeologija 14: 5-79.

Rimantienè R. (1998) The first Narva culture farmers in Lithuania. In: Zvelebil M, Dennel R and Domanska $L$ (eds) Harvesting the Sea, Farming the Forest: The Emergence of Neolithic Societies in the Baltic Region. 1 ed. Somerset, UK: Sheffield Archaeological Monographs 10, Sheffield Academic Press, 213-218.

Rimantienè R. (2005) Akmens amžiaus žvejai prie Pajūrio lagūnos. Šventosios ir Būtingès tyrinejimai., Vilnius: Lietuvos Nacionalinis Muziejus. pp. 166.

Robertson FM, Gundappa MK, Grammes F, et al. (2017) Lineage-specific rediploidization is a mechanism to explain time-lags between genome duplication and evolutionary diversification. Genome Biology 18: 111.

Saito M, Takenouchi Y, Kunisaki N, et al. (2001) Complete primary structure of rainbow trout type I collagen consisting of $\alpha 1$ (I) $\alpha 2$ (I) $\alpha 3$ (I) heterotrimers. The FEBS Journal 268: 2817-2827.

Sloka J. (1986) Zivis Zvidzes mezolīta un neolīta apmetnē (VI-III g.t. p.m.ē). Latvijas PSR Zinātṇu akadēmijas vēstis 9: 127-130. 
Stančikaitè M, Daugnora L, Hjelle K, et al. (2009) The environment of the Neolithic archaeological sites in Šventoji, Western Lithuania. Quaternary International 207: 117-129.

van der Sluis LG, Hollund HI, Buckley M, et al. (2014) Combining histology, stable isotope analysis and ZooMS collagen fingerprinting to investigate the taphonomic history and dietary behaviour of extinct giant tortoises from the Mare aux Songes deposit on Mauritius. Palaeogeography, Palaeoclimatology, Palaeoecology 416: 80-91.

Vizcaíno JA, Csordas A, Del-Toro N, et al. (2016) 2016 update of the PRIDE database and its related tools. Nucleic Acids Research 44: D447-D456.

Weckström K, Lewis JP, Andrén E, et al. (2017) Palaeoenvironmental history of the Baltic Sea: One of the largest Brackish-water ecosystems in the world. In: Weckström K. SK, Gell P., Skilbeck C. (ed) Applications Of Paleoenvironmental Techniques In Estuarine Studies. Dordrecht: Springer, 615-662.

Yurtseva A, Salmina E, Galik A, et al. (2015) How a millennium of fishing changed fish populations: a case study of Lake Peipus and the Velikaya River (NW Russia). Aquatic sciences 77: 325-336.

Zagorska I. (1992) The Mesolithic in Latvia. Acta archaeologica 63: 97-117.

Zeller D, Rossing P, Harper S, et al. (2011) The Baltic Sea: Estimates of total fisheries removals 1950-2007. Fisheries Research 108: 356-363.

Žulkus V. (2002) Viduramžiu Klaipèda, Vilnius: Žara.

Žulkus V and Daugnora L. (2009) What did the order's brothers eat in the Klaipeda Castle? (Historical and zooarchaeological data). Archaeologia Baltica: 74-87.

Zvelebil M. (2006) Mobility, contact, and exchange in the Baltic Sea basin 6000-2000 BC. Journal of Anthropological Archaeology 25: 178-192. 